
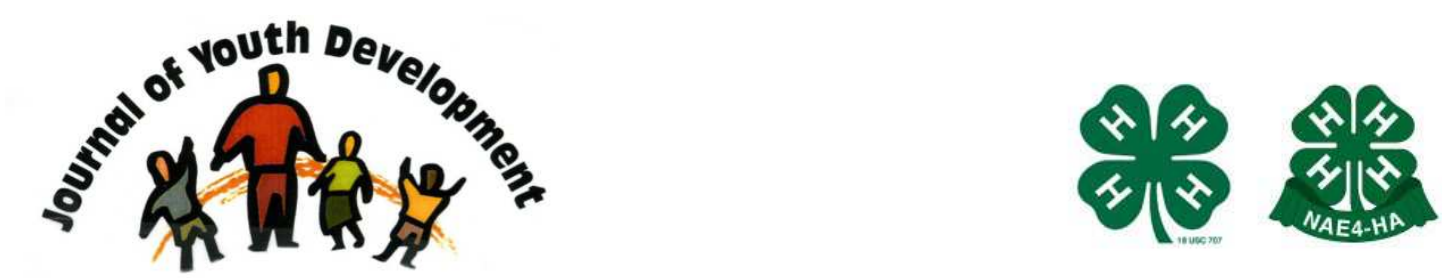

Bridging Research \& Practice

\title{
A Descriptive View of the 4-H Club Experience Through the Lens of 4-H Youth
}

\author{
Lisa A. Guion \\ Agricultural \& Extension Education \\ North Carolina State University \\ Raleigh, NC \\ Lisa Guion@ncsu.edu \\ Blanca E. Rivera \\ Department of Education \\ University of Florida \\ Gainesville, FL
}




\title{
JOURNAL OF YOUTH DEVELOPMENT \\ bridging research and practice

\section{A Descriptive View of the 4-H Club Experience Through the Lens of 4-H Youth}

\author{
Lisa A. Guion \\ North Carolina State University \\ Blanca E. Rivera \\ University of Florida
}

\begin{abstract}
programming:
1. youth participation and leadership,

2. positive adult-youth relationships, and

3. skill building activities (Lerner, 2004).
\end{abstract}

Abstract: 4-H like other youth development programs should be generally marked by the presence of three features of optimal youth

This paper reviews a study which examined the extent to which 4-H youth felt they had "opportunities" to engage in different learning experiences, and provide leadership to those experiences within their clubs. The study also examined the youth's perceptions about whether their experience in the 4-H Club helped them spend more time with their parents, have a positive relationship with another adult and do things independently.

An examination of whether there is a difference in life skill development in 4-H based on certain key demographic variables is also discussed.

The results of this study are shared as well as implications for practice and recommendations for further research.

\section{Introduction}

4-H Youth Development (4-H) is the national youth-serving organization of the Cooperative State Research, Education and Extension Service (CSREES) of the U.S. Department of Agriculture (USDA). 4-H like other youth development programs should be generally marked by the presence of three features of optimal youth programming:

1. youth participation and leadership, 
2. positive adult-youth relationships, and

3. skill building activities (Lerner, 2004).

In this paper, the results of a cross-sectional descriptive evaluation study of a 4-H Youth Development club program based on those three key features are shared.

Using experiential, research-based curricula, 4-H offers many opportunities for youth to be active participants in learning. "All 4-H curricula and projects, regardless of the differences in content area, provide youth with experiences that foster the development of skills and encourage them to become contributing, caring members of their communities" (Mincemoyer, \& Perkins, 2001). 4-H also uses a variety of different delivery modes to reach youth (e.g. community club, camps, after school, school enrichment, etc.). While curricula, activities and delivery modes certainly will and must vary in content and structure, the bottom line is clear that youth need to have opportunities to participate in multiple types of activities that interest them (Theokas, Lerner, Phelps, \& Lerner, 2006). Therefore, this study examined the extent to which 4-H youth felt that they have "opportunities" to engage in different learning experiences, and provide leadership to those experiences within their clubs. The study also explored those learning experiences 4-H'ers felt they engaged in most frequently.

In keeping with the Lerner framework, in addition to positive relationships with their parents, youth need positive, supportive, mentoring relationships with other caring adults (Perkins, \& Butterfield, 1999; Bogenschneider, \& Olsen, 1998). The literature is clear that the most positive youth-adult relationship experiences are those with supportive adults willing to share power with youth and give youth opportunities to lead (Jekielek, Moore, Hair, \& Scarupa, 2002; Jones, 2006; Perkins, Borden, \& Villarruel, 2001). This study examined the youth's perceptions about whether their experience in the 4-H Club helped them spend more time with their parents, have a positive relationship with another adult and do things independently. In addition, this study explored whether 4-H youth felt they received positive feedback from the club leader and helped make decisions in their club.

Building critical life skills is an integral part of positive youth development. The development of life skills through experiential learning continues to be the cornerstone of 4-H youth programming. Numerous studies have shown that it is important to include learning experiences that build and/or enhance life skills into 4-H and other youth development programs (Peterson et al., 2000; Seevers, \& Dormody, 2000). Further studies have shown that participation in 4-H does contribute to life skill development (Astroth, \& Haynes, 2002; Boyd, Herring, \& Briers, 1992).

Using a Life Skills Improvement Scale that had been tested and validated as reliable (Guion, \& Rivera, 2006), this study examined whether 4-H youth felt they have increased nineteen key life skills that prevailed in the literature. In an examination of the current literature there were very few studies that looked descriptively to assess whether there is a difference in life skill development in 4-H based on certain key demographic variables. Also, to date, no studies were found that examined whether there is a relationship between the learning experiences and the life skills that 4-H youth develop.

In essence, this study provides a more descriptive examination of the 4-H club experience by assessing the extent to which 4-H youth perceived their club experience as containing the three key features for youth development: 
1) youth participation and leadership,

2) positive adult-youth relationships, and

3) skill building activities.

In addition to evaluating whether these key features are present, this study also examined the relationship between certain club experiences and life skill development. While not specific to 4- $\mathrm{H}$, other studies have documented significant differences in participation in after-school activities (i.e. types of activities, number of activities, etc.) based on key demographic variables (Bouffard, Wimer, Caronongan, Little, \& Dearing, 2006). Therefore, this study provides insight as to whether perceived life skill development also varied for 4-H youth who differ based on gender, race and age.

\section{Methods}

\section{Participants}

Participants of the study were 126 youth members of 4-H Clubs in Florida, of which $36 \%$ $(n=45)$ were male and $64 \%(n=79)$ female. The average age was 13.8 years, ranging from 7 to 18 years old. Participants have been members of $4-\mathrm{H}$ an average of 4.7 years ranging from 2 months to 12 years. More than half $(66 \%, n=83)$ of the youth in this study described themselves as Caucasian/White, $22 \%$ as African-American $(n=28), 7 \%$ as Hispanic/Latino $(n=9)$, and $5 \%$ described themselves as Other $(n=6)$. Participants and their parents signed informed consent forms and no compensation was provided for participation in the study.

\section{Instrument}

Astroth and Haynes (2002) assert that 4-H clubs are intentionally designed to include the eight critical elements necessary for positive youth development:

- Positive relationships with caring adults; $*$

- Opportunities for self-determination;*

- An accepting and inclusive environment;*

- Opportunities to contribute through community service;*

- A safe environment for learning and growing;

- Opportunities to develop skills and mastery;*

- Engagement in learning*; and

- Opportunities to be an active participant in life- now and in the future."

The evaluation instrument consisted of three sections. The first section asked questions related to six of those critical elements (* indicates those elements included in the instrument). For example, study participants were asked how often they were given a chance to do service projects in their community, make decisions in their club, etc. They were also asked how often they had actually helped decide which projects to do in their club for example.

The second section of the evaluation instrument was the Life Skills Improvement Scale that includes the 19 indicators of life skills development. Each indicator used a five point Likert Scale ranging from strongly disagree (1) to strongly agree (5). The items included in the instrument were determined by conducting two strategic steps. First, the researcher surveyed the literature that conceptualized 4-H life skills. For example, life skills from the Targeting Life 
Skills model (Hendricks, 1998) were identified. Ultimately, life skills from the Texas 4-H evaluation instrument, which is based on the Hendrix model, were adapted for use in the Life Skills Improvement Scale. The Texas model was adapted because "the youth development skills section is a set of statements that are relevant to all project experiences and to youth of all ages and backgrounds." (Howard, et al., 2001, p. 2).

Second, nine Extension 4-H Agents from different districts in the state of Florida were asked to select the life skills that their 4-H program targets. They were also encouraged to add to or refine the list of life skills. Those items that had the greatest level of consensus were chosen for inclusion in the Life Skills Improvement Scale. The Cronbach alpha reliability coefficients for the Life Skills Improvement Scale was .88 above the typical conservative target of at least .80 (Guion, \& Rivera, 2006). The scale was also found to be face valid and had a very high content validity index of 3.8 out of possible 4 (Guion, \& Rivera, 2006). The last section of the evaluation instrument contained key demographic questions.

A copy of the evaluation instrument is provided as an Appendix.

\section{Implementation}

Using a cross-sectional survey design, the instrument was administered at the beginning of a regular 4-H club meeting. Each 4-H Agent participating in the study was provided with consent forms that were signed by the parents, as well as detailed instructions and a script in order to make administration of the instrument more consistent across sites. They were also provided postage paid envelopes to return the survey.

\section{Findings and Implications for Practice and/or Further Research}

\section{Opportunity to Engage In Different Learning Experiences that Foster Youth Participation and Leadership}

Participants "frequently" engaged in different learning experiences that are integral to youth development. Opportunities for having fun was the most frequent ( $M=4.41, S D=.72$ ) followed by opportunities to "feel like part of a group" $(M=4.39, \mathrm{SD}=.85)$. Only "sometimes" they had the opportunity to "be a leader" $(M=3.44, S D=1.35)$ or "speak before a group" ( $M=3.56$, $\mathrm{SD}=1.28$ ) (See Table 1).

\section{Table 1}

Means and standard deviations of opportunities given to club members

\begin{tabular}{|l|c|c|c|}
\hline How often were you given the CHANCE TO... & M & SD & $\mathrm{N}$ \\
\hline have fun & 4.41 & .72 & 126 \\
\hline make new friends & 3.89 & 1.07 & 126 \\
\hline feel like part of a group & 4.39 & .85 & 125 \\
\hline make decisions & 3.91 & 1.06 & 126 \\
\hline speak before a group & 3.56 & 1.28 & 124 \\
\hline be a leader & 3.44 & 1.35 & 124 \\
\hline do service projects & 3.95 & 1.06 & 126 \\
\hline learn record-keeping & 3.73 & 1.15 & 126 \\
\hline Use parliamentary procedure at club meetings & 3.75 & 1.24 & 124 \\
\hline
\end{tabular}


Giving youth the opportunity to develop leadership skills by providing him/her with opportunities to "be a leader" and "speak before a group" are important. These results suggest that club leaders need to find out from the youth what leadership roles they would like to have, then coach and support them in carrying out those roles.

\section{Learning Experiences Related to Positive Youth-Adult Relationships}

Participants frequently "received positive feedback" $(M=4.15, S D=1.01)$; spent time with their parents because of 4-H (4.03, SD=1.07), and "felt successful" (M=4.04, SD=.97). "Been a leader" $(M=3.30, S D=1.38)$ and "spoken before a group" $(M=3.35, S D=1.40)$ were the least frequent experiences they felt that they engaged in with their 4-H club. (See Table 2).

Table 2

Mean and standard deviations

\begin{tabular}{|l|c|c|c|}
\hline How often have you ACTUALLY..... & M & SD & N \\
\hline spoken before a community group & 3.35 & 1.40 & 125 \\
\hline felt successful & 4.04 & .97 & 125 \\
\hline been a leader & 3.30 & 1.38 & 120 \\
\hline help decide which project to do in your club & 3.66 & 1.18 & 122 \\
\hline learned a new skill & 3.67 & 1.23 & 121 \\
\hline $\begin{array}{l}\text { received positive feedback from the club } \\
\text { leader }\end{array}$ & 4.15 & 1.01 & 121 \\
\hline $\begin{array}{l}\text { felt that the club leader respected your } \\
\text { input/ideas }\end{array}$ & 4.01 & .95 & 125 \\
\hline spent time with your parents because of 4-H & 4.03 & 1.07 & 124 \\
\hline
\end{tabular}

$\begin{array}{lllll}\text { Scale: } 1 \text { ) Never } & \text { 2) Rarely } & \text { 3) Sometimes } & 4 \text { ) Frequently } & \text { 5) Always }\end{array}$

Some results related to positive adult-youth relationships are encouraging. The club leaders are providing positive feedback and help youth feel successful, respected and heard. Youth are also spending more time with their parents because of $4-\mathrm{H}$. However, learning by doing also has been the fundamental principle of 4-H since its inception (Woloshuk, Brown, \& Wagaman, 1999). Therefore, more strategies must be employed to provide all youth in the club with opportunities to actually assume more leadership roles, beyond just the club officers, and speaking before community groups. Club leaders should also make sure youth get the opportunity to help decide which projects the club will do (self-determination). These all contribute to positive youth development.

\section{Experience in the 4-H Club}

Almost all participants (93\%) indicated that their experience in the club helped them to "get along well with others in a group." More than eighty percent of participants indicated that their experience in the club helped them to "do things independently," "expect good things from themselves," "have a positive relationship with an adult," and "accept other's views." (See Table 3). 


\section{Table 3}

Experience in the 4-H club

\begin{tabular}{|l|c|c|c|c|c|c|}
\hline \multirow{2}{*}{ My experience in the 4-H club helped me to } & \multicolumn{3}{|c|}{ No } & \multicolumn{2}{c|}{ Yes } & \multicolumn{2}{c|}{ Not Sure } \\
\cline { 2 - 7 } & $\mathrm{n}$ & $\%$ & $\mathrm{n}$ & $\%$ & $\mathrm{~N}$ & $\%$ \\
\hline have a positive relationship with an adult & 6 & 4.8 & 102 & 81.6 & 16 & 12.8 \\
\hline do things on my own (independently) & 2 & 1.6 & 110 & 88.8 & 12 & 9.6 \\
\hline accept other's views & 4 & 3.2 & 100 & 80.0 & 21 & 16.8 \\
\hline get along well with others in a group & 4 & 3.2 & 116 & 92.8 & 5 & 4.0 \\
\hline expect good things from myself & 1 & .8 & 111 & 88.8 & 13 & 10.3 \\
\hline
\end{tabular}

$\mathrm{N}=125$

\section{Improvement in Life Skills}

Participants indicated an increase in the following skills as a result of $4-\mathrm{H}$ club activities and projects: serving the community or volunteering $(M=3.17, S D=.87)$, setting goals $(M=3.14$, $S D=.78)$, making decisions $(M=3.10, S D=.75)$, leading a healthier lifestyle $(M=3.02, S D=.78)$, and feeding and caring for animal/pet $(M=3.01, S D=.90)$. Mean scores for the other 14 life skill indicators ranged from 2.43 to 2.99. These mean scores are relatively low given the emphasis on life skill development within 4-H Youth Development. Further study is needed to fully examine these implications. (See Table 4).

\section{Table 4}

Means and standard deviation of ability developed by club members in several skills

\begin{tabular}{|l|l|l|l|}
\hline $\begin{array}{l}\text { As a result of 4-H, I improved my ability } \\
\text { to... }\end{array}$ & M & SD & N \\
\hline keep accurate records & 2.85 & .78 & 125 \\
\hline plan/organized & 2.99 & .79 & 126 \\
\hline set goals & 3.14 & .78 & 126 \\
\hline solve problems & 2.91 & .80 & 126 \\
\hline make decisions & 3.10 & .75 & 126 \\
\hline serve my community or volunteer & 3.17 & .87 & 125 \\
\hline lead a group & 2.76 & .91 & 126 \\
\hline get ready for a job & 2.90 & .85 & 122 \\
\hline plan my career & 2.84 & .86 & 122 \\
\hline speak publicly & 2.93 & .87 & 126 \\
\hline write more clearly & 2.85 & .80 & 125 \\
\hline resolve conflicts & 2.81 & .80 & 124 \\
\hline Sew & 2.48 & .91 & 124 \\
\hline Cook & 2.63 & .83 & 124 \\
\hline groom an animal/pet & 2.87 & .94 & 122 \\
\hline feed and care for animal/pet & 3.01 & .90 & 122 \\
\hline lead a healthier lifestyle & 3.02 & .78 & 125 \\
\hline use a computer or other technology & 2.93 & .88 & 122 \\
\hline learn photography or other media & 2.71 & .86 & 120 \\
\hline
\end{tabular}

Scale: 1) Strongly Disagree 2) Disagree

3) Neutral

4) Agree

5) Strongly Disagree 
Differences in the Skills Improved based on the Gender of 4-H Club Member

T-tests were conducted to examine the difference by gender. Results showed that the ability to write more clearly increased more in females $(M=2.97, S D=.84)$ than in males $(M=2.64$, $\mathrm{SD}=.71)(\mathrm{t}(122)=2.22, \mathrm{p}<.05)$. An explanatory study is needed to determine whether this difference was due to the types of projects that girls select compared to those that boys prefer. For example, do girls engage more with activities and projects requiring journaling and/or keeping records? If so, then naturally girls would be developing writing skills more. Gender differences were also found in the ability to sew, where females $(M=2.64, S D=.93)$ scored higher than males $(M=2.25, S D=.78)(t(120)=2.37, p<.05)$. This difference may be the result of there simply being more females involved in club projects related to clothing/sewing. However, it is very encouraging that 17 of the 19 life skills developed did not differ significantly for boys and girls. 4-H has always maintained its gender neutrality. This result supports that claim. (See Table 5).

Table 5

Group differences for the skills improved by gender

\begin{tabular}{|l|c|c|c|c|c|c|c|c|}
\hline & \multicolumn{3}{|c|}{ Males } & \multicolumn{3}{c|}{ Females } & & \\
\hline $\begin{array}{l}\text { As a result of 4-H, I improved } \\
\text { my ability to... (Likert Scale) }\end{array}$ & $\mathrm{M}$ & $\mathrm{SD}$ & $\mathrm{n}$ & $\mathrm{M}$ & $\mathrm{SD}$ & $\mathrm{N}$ & $\mathrm{t}$ & $\mathrm{DF}$ \\
\hline keep accurate records & 2.68 & .85 & 45 & 2.94 & .74 & 78 & 1.68 & 121 \\
\hline plan/organize & 2.87 & .87 & 45 & 3.08 & .75 & 79 & 1.41 & 122 \\
\hline set goals & 3.04 & .77 & 45 & 3.20 & .79 & 79 & 1.08 & 122 \\
\hline solve problems & 3.02 & .72 & 45 & 2.84 & .84 & 79 & 1.25 & 122 \\
\hline make decisions & 3.13 & .73 & 45 & 3.08 & .76 & 79 & .41 & 122 \\
\hline $\begin{array}{l}\text { serve my community or } \\
\text { volunteer }\end{array}$ & 3.11 & .81 & 44 & 3.19 & .91 & 79 & .46 & 121 \\
\hline lead a group & 2.67 & .90 & 45 & 2.81 & .92 & 79 & .84 & 122 \\
\hline get ready for a job & 2.96 & .77 & 45 & 2.87 & .91 & 75 & .55 & 118 \\
\hline plan my career & 2.82 & .78 & 45 & 2.85 & .91 & 75 & .19 & 118 \\
\hline speak publicly & 2.82 & .89 & 45 & 3.00 & .86 & 79 & 1.09 & 122 \\
\hline write more clearly & 2.64 & .71 & 45 & 2.97 & .84 & 78 & $2.22 *$ & 121 \\
\hline solve conflicts & 2.84 & .81 & 44 & 2.79 & .81 & 78 & .30 & 120 \\
\hline sew & 2.25 & .78 & 44 & 2.64 & .93 & 78 & $2.37 *$ & 120 \\
\hline cook & 2.60 & .75 & 45 & 2.69 & .85 & 77 & .58 & 120 \\
\hline groom an animal/pet & 2.76 & .83 & 45 & 2.92 & .99 & 75 & .93 & 118 \\
\hline feed and care for animal/pet & 2.89 & .83 & 45 & 3.01 & .95 & 75 & 1.04 & 118 \\
\hline lead a healthier lifestyle & 3.02 & .69 & 45 & 3.01 & .83 & 78 & .06 & 121 \\
\hline $\begin{array}{l}\text { use a computer/other } \\
\text { technology }\end{array}$ & 2.98 & .87 & 45 & 2.88 & .90 & 75 & .58 & 118 \\
\hline $\begin{array}{l}\text { learn photography or other } \\
\text { media }\end{array}$ & 2.76 & .86 & 45 & 2.70 & .76 & 73 & .35 & 116 \\
\hline
\end{tabular}

$* p<.05$ two-tailed

\section{Differences in Life Skills Improvement based on the Race/Ethnicity of the 4-H Club Member \\ Because only 7 participants identified themselves as Hispanic/Latino and 5 indicated "other," t-test analyses were conducted only with the group of African-American/Black and Caucasian/White 4-H youth. Results showed that African-American/Black participants scored}


significantly higher than Caucasian/White in planning/organizing, setting goals, writing more clearly, solving problems, sewing, cooking, using a computer, and learning photography. (See Table 6).

Table 6

Group differences for the skills improved by group of race/ethnicity

\begin{tabular}{|l|c|c|c|c|c|c|c|c|}
\hline & \multicolumn{3}{|c|}{ African-American } & \multicolumn{3}{c|}{ Caucasian/White } & & \\
\hline $\begin{array}{l}\text { As a result of 4-H, I improved } \\
\text { my ability to... (Likert Scale) }\end{array}$ & $\mathrm{M}$ & $\mathrm{SD}$ & $\mathrm{N}$ & $\mathrm{M}$ & $\mathrm{SD}$ & $\mathrm{N}$ & $\mathrm{T}$ & $\mathrm{DF}$ \\
\hline keep accurate records & 2.96 & .71 & 27 & 2.77 & .82 & 82 & 1.10 & 107 \\
\hline plan/organize & 3.28 & .66 & 28 & 2.89 & .82 & 82 & $2.32^{* *}$ & 108 \\
\hline set goals & 3.61 & .50 & 28 & 3.00 & .80 & 82 & $3.76^{*}$ & 108 \\
\hline solve problems & 2.82 & .98 & 28 & 2.94 & .74 & 82 & .66 & 108 \\
\hline make decisions & 3.21 & .74 & 28 & 3.01 & .75 & 82 & .86 & 108 \\
\hline $\begin{array}{l}\text { serve my community or } \\
\text { volunteer }\end{array}$ & 3.39 & .92 & 28 & 3.04 & .87 & 81 & 1.84 & 107 \\
\hline lead a group & 2.82 & .90 & 28 & 2.78 & .93 & 82 & .20 & 108 \\
\hline get ready for a job & 3.00 & 1.04 & 25 & 2.93 & .82 & 81 & .37 & 104 \\
\hline plan my career & 2.88 & .88 & 25 & 2.95 & .85 & 81 & .36 & 104 \\
\hline speak publicly & 2.86 & 1.04 & 28 & 2.93 & .86 & 82 & .51 & 108 \\
\hline write more clearly & 3.25 & .70 & 28 & 2.72 & .78 & 81 & $3.21^{*}$ & 107 \\
\hline solve conflicts & 3.15 & .91 & 27 & 2.70 & .77 & 81 & $2.49^{* *}$ & 106 \\
\hline Sew & 3.22 & .89 & 27 & 2.27 & .74 & 81 & $5.48^{*}$ & 106 \\
\hline Cook & 3.15 & .77 & 27 & 2.52 & .73 & 81 & $3.84 *$ & 106 \\
\hline groom an animal/pet & 2.56 & 1.08 & 25 & 2.98 & .89 & 81 & 1.93 & 104 \\
\hline feed and care for animal/pet & 2.72 & 1.06 & 25 & 3.12 & .86 & 81 & 1.94 & 104 \\
\hline lead a healthier lifestyle & 3.21 & .77 & 28 & 2.99 & .77 & 81 & 1.34 & 107 \\
\hline $\begin{array}{l}\text { use a computer or other } \\
\text { technology }\end{array}$ & 3.43 & .74 & 28 & 2.78 & .88 & 78 & $3.48^{*}$ & 104 \\
\hline $\begin{array}{l}\text { learn photography or other } \\
\text { media }\end{array}$ & 3.21 & .77 & 24 & 2.59 & .82 & 80 & $3.28^{*}$ & 102 \\
\hline
\end{tabular}

$* \mathrm{p}<.01$ two-tailed. $* * \mathrm{p}<.05$ two-tailed

These results suggest that the aforementioned skills were improved more in the group of African-Americans than in the group of Caucasian/White participants. Mean scores were higher for African-Americans for 14 of the 19 life skills, and significantly (statistically) higher for 8 of the 19. An explanatory study would be needed to determine "why" African-American 4-H youth feel they are improving more skills as a result of $4-\mathrm{H}$ club involvement. For example, further study to examine different ethnic groups' in involvement in other youth programs and therefore could not contribute skill development solely to $4-\mathrm{H}$. Also, a study to assess any difference in pre-existing knowledge or mastery of skills and perceptions of skill improvement may reveal the reasons behind these results.

Difference in Life Skills Improvement based on the Age of the 4-H Club Member To examine differences by age the group was divided into two groups, younger participants (from 7 to 13 years old) and older participants (from 14 to 19 years old). Results showed that older participants scored significantly higher than younger ones in leading a group, planning their career, and speaking publicly. (See Table 7) These results suggest that the 
aforementioned skills increased more in the group of older participants than in the younger group. The increase in the types of skills for the older 4-H youth seems logical given the difference in ages and stages of development between the groups. For example, it is feasible that the older youth would be improving skills in planning their career more so than the younger youth. The key implication for this finding is that irrespective of age, 4-H youth in this study are developing key life skills namely setting goals, making decisions, serving their community/volunteering (i.e. skills where $\mathrm{M}$ for both age groups > 3.00).

\section{Table 7}

Group differences for the skills developed by group of age

\begin{tabular}{|l|c|c|c|c|c|c|c|c|}
\hline & \multicolumn{3}{|c|}{ Younger } & \multicolumn{3}{c|}{ Older } & & \\
\hline $\begin{array}{l}\text { As a result of 4-H, I improved } \\
\text { my ability to... (Likert Scale) }\end{array}$ & $\mathrm{M}$ & $\mathrm{SD}$ & $\mathrm{N}$ & $\mathrm{M}$ & $\mathrm{SD}$ & $\mathrm{N}$ & $\mathrm{t}$ & $\mathrm{DF}$ \\
\hline keep accurate records & 2.75 & .78 & 55 & 2.93 & .79 & 70 & 1.30 & 123 \\
\hline plan/organize & 2.89 & .88 & 56 & 3.07 & .73 & 70 & 1.26 & 124 \\
\hline set goals & 3.07 & .85 & 56 & 3.20 & .71 & 70 & .92 & 124 \\
\hline solve problems & 2.79 & .82 & 56 & 3.01 & .77 & 70 & 1.60 & 124 \\
\hline make decisions & 3.05 & .80 & 56 & 3.14 & .71 & 70 & .67 & 124 \\
\hline $\begin{array}{l}\text { serve my community or } \\
\text { volunteer }\end{array}$ & 3.07 & .93 & 56 & 3.25 & .81 & 69 & 1.12 & 123 \\
\hline lead a group & 2.43 & .91 & 56 & 3.03 & .82 & 70 & $3.89 *$ & 124 \\
\hline get ready for a job & 2.75 & .88 & 53 & 3.01 & .81 & 69 & 1.69 & 120 \\
\hline plan my career & 2.57 & .84 & 53 & 3.04 & .81 & 69 & $3.16 *$ & 120 \\
\hline speak publicly & 2.71 & .91 & 56 & 3.10 & .80 & 70 & $2.53 *$ & 124 \\
\hline write more clearly & 2.88 & .85 & 56 & 2.83 & .77 & 69 & .34 & 123 \\
\hline solve conflicts & 2.78 & .88 & 55 & 2.84 & .74 & 69 & .41 & 122 \\
\hline sew & 2.60 & 1.06 & 55 & 2.38 & .75 & 69 & 1.37 & 122 \\
\hline cook & 2.76 & .92 & 55 & 2.52 & .74 & 69 & 1.62 & 122 \\
\hline groom an animal/pet & 2.81 & .98 & 53 & 2.91 & .90 & 69 & .59 & 120 \\
\hline feed and care for animal/pet & 3.07 & .94 & 53 & 2.96 & .88 & 69 & .72 & 120 \\
\hline lead a healthier lifestyle & 3.14 & .72 & 56 & 2.93 & .81 & 69 & 1.55 & 123 \\
\hline $\begin{array}{l}\text { use a computer or other } \\
\text { technology }\end{array}$ & 3.06 & .91 & 53 & 2.83 & .86 & 69 & 1.44 & 120 \\
\hline $\begin{array}{l}\text { learn photography or other } \\
\text { media }\end{array}$ & 2.63 & .96 & 51 & 2.77 & .79 & 69 & .88 & 118 \\
\hline
\end{tabular}

$* \mathrm{p}<.05$ two-tailed

\section{Relationships between the activities done by 4-H Club Members and the Life Skills Improvement}

Correlation analyses were conducted to determine whether there is a relationship between the learning experiences $4-\mathrm{H}$ youth engage in and the life skills they develop. Results are shown in Table 8. Only those correlations higher or equal to .30 will be mentioned here. Those participants that actually spoke before a group more frequently had an increase in their ability to speak publicly $(r=.50, p<.01)$, lead a group $(r=.49, p<.01)$, and make decisions $(r=.35, p<.01)$. Those who felt successful more frequently had an increase in their ability to make decisions $(r=.37, p<.01)$, solve problems $(r=.36, p<.01)$, groom an animal/pet $(r=.34$, $p<.01)$, keep accurate records $(r=.32, p<.01)$, lead a group $(r=.31, p<.01)$, serve the 
community $(r=.31, p<.01)$, get ready for a job $(r=.31, p<.01)$, and plan their career $(r=.30$, $\mathrm{p}<.01)$.

Participants that were a leader more frequently had an increase in their ability to lead a group $(r=.70, p<01)$, serve the community or volunteer $(r=.40, p<.01)$, make decisions $(r=.34$, $\mathrm{p}<.05)$, and plan/organize $(r=.33, p<.01)$. Those who helped decide which projects to do in the club had an increase in their ability to serve their community or volunteer $(r=.37, p<.01)$, plan/organize $(r=.36, p<.01)$, lead a group $(r=.36, p<.01)$, and plan their career $(r=.33$, $\mathrm{p}<.01)$.

Those who learned a new skill had an increase in their ability to write more clearly $(r=.44$, $p<.05)$, learn photography $(r=.44, p<.01)$, cook $(r=.42, p<.01)$, sew $(r=.40, p<.01)$, solve problems $(r=.34, p<.01)$, plan/organize $(r=.32, p<.01)$, and plan their career $(r=.32, p<.01)$. Participants that received positive feedback from the club leader more frequently had an increase in their ability to serve the community or volunteer $(r=.46, p<.01)$, make decisions $(r=.38, p<.01)$, resolve conflicts $(r=.36, p<.01)$, solve problems $(r=.30, p<.01)$, and learn photography $(r=.30, p<.01)$.

Participants who spent time with their parents more frequently because of $4-\mathrm{H}$, had an increase in their ability to plan/organize $(r=.30, p<.01)$, write more clearly $(r=.37, p<.01)$, keep accurate records $(r=.36, p<.01)$, solve problems $(r=.33, p<.01)$, set goals $(r=.33, p<.01)$, and speak publicly $(r=.30, p<.01)$. Finally, those who used parliamentary procedures at the club meetings had an increase in their ability to lead a group $(r=.40, p<.01)$, plan/organize $(r=.42, p<.01)$, serve the community or volunteer $(r=.40, p<.01)$, resolve conflicts $(r=.37$, $p<.01)$, learn photography $(r=.36, p<.01)$, set goals $(r=.35, p<.01)$, make decisions $(r=.33$, $\mathrm{p}<.01)$, and speak publicly $(r=.30, \mathrm{p}<.01)$. 
Table 8

Relationship Between Activities and Skills

\begin{tabular}{|c|c|c|c|c|c|c|c|c|}
\hline & Spoke & Success & Leader & Decided & Learned & Feedback & Parents & Meetings \\
\hline $\begin{array}{l}\text { keep accurate } \\
\text { records }\end{array}$ & $\begin{array}{c}.22^{*} \\
(124)\end{array}$ & $\begin{array}{l}.32 * * \\
(124)\end{array}$ & $\begin{array}{c}.26^{*} \\
(120)\end{array}$ & $\begin{array}{l}.18 \\
(121)\end{array}$ & $\begin{array}{c}.21^{*} \\
(121)\end{array}$ & $\begin{array}{c}.17 \\
(120)\end{array}$ & $\begin{array}{l}.36 * * \\
(123)\end{array}$ & $\begin{array}{l}.25^{* *} \\
(123)\end{array}$ \\
\hline Plan/organize & $\begin{array}{l}.24 * * \\
(125)\end{array}$ & $\begin{array}{l}.29 * * \\
(125)\end{array}$ & $\begin{array}{l}.33 * * \\
(120) \\
\end{array}$ & $\begin{array}{l}.36^{* *} \\
(122) \\
\end{array}$ & $\begin{array}{l}.32 * * \\
(121)\end{array}$ & $\begin{array}{l}.29 * * \\
(121)\end{array}$ & $\begin{array}{l}.39 * * \\
(124) \\
\end{array}$ & $\begin{array}{l}.42 * * \\
(124) \\
\end{array}$ \\
\hline set goals & $\begin{array}{c}.10 \\
(125)\end{array}$ & $\begin{array}{l}.29 * * \\
(125) \\
\end{array}$ & $\begin{array}{l}.29 * * \\
(120) \\
\end{array}$ & $\begin{array}{l}.22^{*} \\
(122) \\
\end{array}$ & $\begin{array}{l}.23^{*} \\
(121)\end{array}$ & $\begin{array}{l}.27^{*} \\
(121) \mathrm{z}\end{array}$ & $\begin{array}{l}.33^{* *} \\
(124) \\
\end{array}$ & $\begin{array}{l}.35^{* *} \\
(124) \\
\end{array}$ \\
\hline solve problems & $\begin{array}{l}.27^{* *} \\
(125)\end{array}$ & $\begin{array}{l}.21^{*} \\
(125) \\
\end{array}$ & $\begin{array}{c}.18 \\
(120) \\
\end{array}$ & $\begin{array}{l}.16 \\
(122) \\
\end{array}$ & $\begin{array}{l}.12 \\
(121)\end{array}$ & $\begin{array}{l}.30 * * \\
(121)\end{array}$ & $\begin{array}{l}.33 * * \\
(124) \\
\end{array}$ & $\begin{array}{l}.21^{*} \\
(124)\end{array}$ \\
\hline make decision & $\begin{array}{l}.35^{* *} \\
(125)\end{array}$ & $\begin{array}{l}.37 * * \\
(125)\end{array}$ & $\begin{array}{l}.34 * * \\
(120) \\
\end{array}$ & $\begin{array}{l}.20^{*} \\
(122) \\
\end{array}$ & $\begin{array}{l}.29 * * \\
(121)\end{array}$ & $\begin{array}{l}.38^{* *} \\
(121)\end{array}$ & $\begin{array}{l}.26 * * \\
(124)\end{array}$ & $\begin{array}{l}.33 * * \\
(124)\end{array}$ \\
\hline $\begin{array}{l}\text { serve my } \\
\text { community }\end{array}$ & $\begin{array}{l}.21^{*} \\
(124)\end{array}$ & $\begin{array}{l}.31^{* *} \\
(124) \\
\end{array}$ & $\begin{array}{l}.40 * * \\
(119) \\
\end{array}$ & $\begin{array}{l}.37 * * \\
(121) \\
\end{array}$ & $\begin{array}{c}.18 \\
(120) \\
\end{array}$ & $\begin{array}{l}.46 * * \\
(120)\end{array}$ & $\begin{array}{l}.26 * * \\
(123) \\
\end{array}$ & $\begin{array}{l}.40 * * \\
(123) \\
\end{array}$ \\
\hline Lead a group & $\begin{array}{l}.49 * * \\
(125) \\
\end{array}$ & $\begin{array}{l}.31^{* *} \\
(125) \\
\end{array}$ & $\begin{array}{l}.70 * * \\
(120) \\
\end{array}$ & $\begin{array}{l}.36^{* *} \\
(122) \\
\end{array}$ & $\begin{array}{c}.12 \\
(121)\end{array}$ & $\begin{array}{c}.21^{*} \\
(121)\end{array}$ & $\begin{array}{c}.13 \\
(124) \\
\end{array}$ & $\begin{array}{l}.48^{* *} \\
(124) \\
\end{array}$ \\
\hline get ready for a job & $\begin{array}{c}.15 \\
(121) \\
\end{array}$ & $\begin{array}{l}.31^{* *} \\
(121) \\
\end{array}$ & $\begin{array}{l}.24 * * \\
(117) \\
\end{array}$ & $\begin{array}{l}.22^{*} \\
(118) \\
\end{array}$ & $\begin{array}{l}.28^{*} \\
(118)\end{array}$ & $\begin{array}{l}.26 * * \\
(117)\end{array}$ & $\begin{array}{l}.26 * * \\
(120) \\
\end{array}$ & $\begin{array}{l}.28^{* *} \\
(120) \\
\end{array}$ \\
\hline Plan my career & $\begin{array}{c}.16 \\
(121) \\
\end{array}$ & $\begin{array}{l}.30^{* *} \\
(121) \\
\end{array}$ & $\begin{array}{l}.25^{* *} \\
(117) \\
\end{array}$ & $\begin{array}{l}.33^{* *} \\
(118) \\
\end{array}$ & $\begin{array}{l}.32 * * \\
(118)\end{array}$ & $\begin{array}{l}.23^{*} \\
(117)\end{array}$ & $\begin{array}{l}.26 * * \\
(120) \\
\end{array}$ & $\begin{array}{l}.23^{*} \\
(120) \\
\end{array}$ \\
\hline speak publicly & $\begin{array}{l}.50 * * \\
(125) \\
\end{array}$ & $\begin{array}{l}.25^{* *} \\
(125) \\
\end{array}$ & $\begin{array}{l}.22^{*} \\
(120) \\
\end{array}$ & $\begin{array}{l}.22^{*} \\
(122) \\
\end{array}$ & $\begin{array}{l}.21^{*} \\
(121) \\
\end{array}$ & $\begin{array}{l}.24 * * \\
(121)\end{array}$ & $\begin{array}{l}.30 * * \\
(124) \\
\end{array}$ & $\begin{array}{l}.30 * * \\
(124) \\
\end{array}$ \\
\hline write more clearly & $\begin{array}{c}.03 \\
(124) \\
\end{array}$ & $\begin{array}{l}.22 * \\
(124) \\
\end{array}$ & $\begin{array}{c}.16 \\
(119) \\
\end{array}$ & $\begin{array}{l}.23^{*} \\
(121) \\
\end{array}$ & $\begin{array}{l}.44^{*} \\
(120)\end{array}$ & $\begin{array}{l}.23^{*} \\
(120) \\
\end{array}$ & $\begin{array}{l}.37 * * \\
(123) \\
\end{array}$ & $\begin{array}{l}.24 * * \\
(123) \\
\end{array}$ \\
\hline resolve conflicts & $\begin{array}{l}.24 * * \\
(123) \\
\end{array}$ & $\begin{array}{l}.36^{* *} \\
(123) \\
\end{array}$ & $\begin{array}{l}.31^{* *} \\
(120) \\
\end{array}$ & $\begin{array}{l}.22^{*} \\
(120) \\
\end{array}$ & $\begin{array}{l}.34 * * \\
(120)\end{array}$ & $\begin{array}{l}.36^{* *} \\
(119)\end{array}$ & $\begin{array}{l}.23^{*} \\
(122) \\
\end{array}$ & $\begin{array}{l}.37 * * \\
(122) \\
\end{array}$ \\
\hline Sew & $\begin{array}{c}-.08 \\
(123) \\
\end{array}$ & $\begin{array}{c}.08 \\
(123) \\
\end{array}$ & $\begin{array}{c}.21^{*} \\
(118) \\
\end{array}$ & $\begin{array}{l}.23^{*} \\
(120) \\
\end{array}$ & $\begin{array}{l}.40 * * \\
(119) \\
\end{array}$ & $\begin{array}{l}.19^{*} \\
(119) \\
\end{array}$ & $\begin{array}{c}.10 \\
(122) \\
\end{array}$ & $\begin{array}{l}.20^{*} \\
(122) \\
\end{array}$ \\
\hline Cook & $\begin{array}{c}.14 \\
(123) \\
\end{array}$ & $\begin{array}{c}-.01 \\
(123) \\
\end{array}$ & $\begin{array}{c}-.00 \\
(118) \\
\end{array}$ & $\begin{array}{l}.06 \\
(120) \\
\end{array}$ & $\begin{array}{l}.42 * * \\
(119)\end{array}$ & $\begin{array}{c}-.08 \\
(119)\end{array}$ & $\begin{array}{c}.05 \\
(122) \\
\end{array}$ & $\begin{array}{c}-.01 \\
(122) \\
\end{array}$ \\
\hline $\begin{array}{l}\text { groom an } \\
\text { animal/pet }\end{array}$ & $\begin{array}{c}-.04 \\
(121) \\
\end{array}$ & $\begin{array}{l}.34 * * \\
(121) \\
\end{array}$ & $\begin{array}{c}.05 \\
(117) \\
\end{array}$ & $\begin{array}{l}.16 \\
(118) \\
\end{array}$ & $\begin{array}{c}.12 \\
(118)\end{array}$ & $\begin{array}{l}.25^{* *} \\
(117)\end{array}$ & $\begin{array}{l}.24 * * \\
(120) \\
\end{array}$ & $\begin{array}{c}.05 \\
(120) \\
\end{array}$ \\
\hline $\begin{array}{l}\text { Feed \& care for } \\
\text { animal/pet }\end{array}$ & $\begin{array}{c}.12 \\
(121) \\
\end{array}$ & $\begin{array}{l}.29 * * \\
(121)\end{array}$ & $\begin{array}{c}-.02 \\
(117) \\
\end{array}$ & $\begin{array}{l}.06 \\
(118)\end{array}$ & $\begin{array}{l}.21^{*} \\
(118)\end{array}$ & $\begin{array}{l}.19^{*} \\
(117) \\
\end{array}$ & $\begin{array}{l}.26 * * \\
(120) \\
\end{array}$ & $\begin{array}{c}.08 \\
(120) \\
\end{array}$ \\
\hline $\begin{array}{l}\text { Lead a healthier } \\
\text { lifestyle }\end{array}$ & $\begin{array}{c}-04 \\
(124) \\
\end{array}$ & $\begin{array}{l}.25^{* *} \\
(124) \\
\end{array}$ & $\begin{array}{c}.15 \\
(119) \\
\end{array}$ & $\begin{array}{l}.10 \\
(121) \\
\end{array}$ & $\begin{array}{l}.27^{* *} \\
(120) \\
\end{array}$ & $\begin{array}{l}.26 * * \\
(120) \\
\end{array}$ & $\begin{array}{c}.17 \\
(123) \\
\end{array}$ & $\begin{array}{c}.18 \\
(123) \\
\end{array}$ \\
\hline $\begin{array}{l}\text { use a computer or } \\
\text { other technology }\end{array}$ & $\begin{array}{c}-.11 \\
(121) \\
\end{array}$ & $\begin{array}{c}.13 \\
(121) \\
\end{array}$ & $\begin{array}{c}.16 \\
(116) \\
\end{array}$ & $\begin{array}{l}.15 \\
(118) \\
\end{array}$ & $\begin{array}{l}.27^{* *} \\
(118)\end{array}$ & $\begin{array}{l}.22^{*} \\
(117)\end{array}$ & $\begin{array}{c}.18 \\
(120) \\
\end{array}$ & $\begin{array}{l}.26 * * \\
(120) \\
\end{array}$ \\
\hline $\begin{array}{l}\text { learn photography } \\
\text { or other media }\end{array}$ & $\begin{array}{c}.04 \\
(119) \\
\end{array}$ & $\begin{array}{l}.36^{* *} \\
(119) \\
\end{array}$ & $\begin{array}{c}.15 \\
(115) \\
\end{array}$ & $\begin{array}{l}.12 \\
(116) \\
\end{array}$ & $\begin{array}{l}.44 * * \\
(117)\end{array}$ & $\begin{array}{l}.30 * * \\
(116)\end{array}$ & $\begin{array}{l}.24 * * \\
(118) \\
\end{array}$ & $\begin{array}{l}.36^{* *} \\
(118) \\
\end{array}$ \\
\hline
\end{tabular}

Note: Spoken $=$ spoken before a group. Success $=$ felt successful. Leader $=$ been a leader. Decided $=$ helped decide which projects to do in the club. Learned $=$ learned new skills. Feedback $=$ received positive feedback from the club leaders.

Parents $=$ spend time with parents because of $4-\mathrm{H}$. Meetings $=$ used parliamentary procedures at a club meeting.

$* \mathrm{p}<.01$. The number of respondents is in parenthesis.

\section{Further Study}

More descriptive studies that look at what specific learning experiences are being provided in 4-H clubs and how these experiences contribute to the critical elements of positive youth development are warranted. This study has demonstrated that we can not only look at outcomes and impacts of programming without spending enough time assessing and understanding the learning experiences and environments that are supposed to produce those outcomes/impacts. 
This study focused only on the 4-H Club delivery system. Additional studies with youth who are involved with 4-H through other delivery modes such as 4-H After-school Programming, 4-H Camping Program, or 4-H School Enrichment would be very helpful in examining the different contexts in which 4-H Youth Development is taking place. This type of study is not limited to 4- $\mathrm{H}$ youth development. Other youth serving organizations could conduct a similar study.

Additionally, while the sample size was sufficient for statistical analysis, further studies should be conducted with larger sample sizes that have even greater age, gender, and race/ethnic diversity.

Finally, given the nature of descriptive studies, a foundation was laid for more specific research questions that must be answered through explanatory research that can answer the question "why." Descriptive studies like the one presented in this paper can provide the catalyst for further scholarship and refinement of knowledge in the field of 4- $\mathrm{H}$ Youth Development.

\section{Conclusion}

4-H youth development has a long, rich history of enhancing the lives of young people across this nation. Descriptive studies like the one presented in this paper provide a glimpse into the 4-H Club which is one of the hallmark 4-H programming delivery systems. These types of studies help us examine what 4-H youth perceive to be key elements of positive youth development that are being reinforced through their club experience. In this study, the key elements of positive youth development that were explored included:

1) youth participation and leadership,

2) positive adult-youth relationships, and

3) skill building activities.

By focusing even more purposefully on designing and implementing learning experiences that reflect positive youth development, $4-\mathrm{H}$ will continue to be a powerful, proven program of excellence in the field of youth development.

\section{References}

Astroth, K.A., \& Haynes, G.W. (2002). More than cows and cooking: Newest research shows the impact of 4-H. Journal of Extension, 40(4). Available online at:

http://www.joe.org/joe/2002august/a6.shtml

Bogenschneider, K., \& Olsen, J. (1998). Building resiliency and reducing risks: What youth need from families and communities. (research brief) Madison, WI: Wisconsin Family Impact Seminars.

Bouffard, S.M., Wimer, C., Caronongan, P., Little, P.M.D, \& Dearing, E. (2006). Demographic differences in patterns in youth out-of-school time activity participation. Journal of Youth Development: Bridging Research and Practice, 1 (2). Available online at: http://www.nae4ha.org/directory/jyd/jyd article.aspx?id=ac838aeb-7ab2-4ca1-bac0$\underline{26 c c a c 9637 d 6}$ 
Boyd, B.L., Herring, D.R., \& Briers, G.E. (1992). Developing life skills in youth. Journal of Extension, 30 (4). Available online at http://www.joe.org/joe/1992winter/a4.html

Dziuban, C.D., \& Shirkey, E.C. (1974). When is a correlation matrix appropriate for factor analysis? Some decision rules. Psychological Bulletin, 81(6), 358-361.

Guion, L.A., \& Rivera, B.E. (2006). Development of a measure of youth's perceptions of the benefits of 4-H involvement. Journal of Youth Development: Bridging Research and Practice, 1 (2). Available online at http://www.nae4ha.org/directory/jyd/jyd article.aspx?id=151e1148-af2c$\underline{4 f 1 c-b 51 c-e f 5 d e 5649 b 2 b}$

Hendricks, P. (1998). Targeting life skills model. Iowa State University. Available online at: http://www.extension.iastate.edu/4H/lifeskills

Howard, J.W., Boleman, C.T., Alvey, A., Burkhum, A.B., Chilek, K.D., Stone, C.C., et al. (2001). Developing a program evaluation instrument for Texas 4-H: A work in progress. Journal of Extension, 39(4). Available online at: http://www.joe.org/joe/2001august/iw4.html

Jekielek, S.M., More, K.A., Hair, E.C., \& Scarupa, H.J. (2002, February). Mentoring: A promising strategy for youth development (research brief). Washington, DC: Child Trends.

Jones, K.R. (2006). Relationships matter: A mixed method evaluation of youth and adults working together as partners. Journal of Youth Development $\sim$ Bridging Research and Practice, 1(2). Available online at: http://www.nae4ha.org/directory/jyd/jyd article.aspx?id=8cf1e185$\underline{60 d 4-4833-b f 55-9 e 5 c f f b f f b a 1}$

Kleinbaum, D.G., Kupper, L.L., \& Muller, K.E. (1988). Applied regression analysis and other multivariable methods (2nd ed.). Boston, MA: PWS-Kent Publ.

Lerner, R.M. (2004). Liberty: Thriving and civic engagement among American youth. Thousand Oaks, CA: Sage.

Mincemoyer, C.C., \& Perkins, D.F. (2001). Building your youth development toolkit: A community youth development orientation for Pennsylvania 4-H/youth programs. Journal of Extension, 39(4). Available online at: http://www.joe.org/joe/2001august/a7.html

Perkins, D.F., Borden, L.M., \& Villarruel, F.A. (2001). Community youth development: A partnership for change. School Community Journal, 11, 39-56.

Perkins, D.F., \& Butterfield, J.R. (1999). Building an asset-based program in 4-H. Journal of Extension, 37(4). Available online at: http://www.joe.org/joe/1999august/a2.html

Peterson, B., Gerhard, G., Hunter, K., Marek, L., Phillips, C., \& Titcomb A. (2000). National 4-H impact assessment project: Perspectives from a nationwide survey. National 4-H. Available online at: http://www.national4-hheadquarters.gov 
Seevers, B.S., \& Dormody, T.J. (2000). 4-H youth participation in leadership development activities: A tri-state study. Journal of Agricultural Education, 35 (4), 49-54.

Theokas, C., Lerner, J.V., Phelps, E., \& Lerner, R.M. (2006). Cacophony and change in youth after school activities: Findings from the 4-H study on positive youth development. Journal of Youth Development Bridging Research and Practice 1(1). Available online at:

http://www.nae4ha.org/directory/jyd/jyd article.aspx?id=5adc7e52-3885-4fd4-b981$\underline{\mathrm{c} 6 \mathrm{e} 72 \mathrm{~b} 9841 \mathrm{~d} 1}$

Woloshuk, J.M., Brown, G., \& Wagaman, G.D. (1999). 4-H projects: Is completion important? Journal of Extension, 37(5). Available online at: http://www.joe.org/joe/1999october/4b5.html

(C) Copyright of Journal of Youth Development Bridging Research and Practice. Content may not be copied or emailed to multiple sites or posted to a listserv without copyright holder's express written permission. Contact Editor at: patricia.dawson@oregonstate.edu for details. However, users may print, download or email articles for individual use.

ISSN 2325-4009 (Print); ISSN 2325-4017 (Online) 